\title{
As grandes ferrovias e o capitalismo monopolista nos EUA do século XIX
}

\author{
José Augusto Drummond*
}

WHITE, Richard. Railroaded: the transcontinentals and the making of modern America. Nova York: Norton, 2011.

Richard White (n. 1947) é professor de história da Stanford University, Califórnia (EUA). É um dos fundadores do campo da história ambiental e um conhecido historiador revisionista do Oeste dos EUA. Publica artigos e livros incisivos e influentes. Seus melhores livros de história ambiental são Land use, environment and social change (Seattle: University of Washington Press, 1980) e The organic machine (Nova York: Hill and Wang, 1995), mas suas obras principais até 2011 eram "It's your misfortune and none of my own" (Norman: University of Oklahoma Press, 1991) e The middle ground (Nova York: Cambridge University Press, 1991), que pertencem à sua produção sobre o Oeste dos EUA. Este recém-lançado Railroaded também pertence a essa segunda linhagem e se candidata a ser a obra de maior fôlego de sua carreira.

A temática de White nesse novo livro pode ser assim resumida: trata da história política do nascimento do capitalismo monopolista dos EUA, em sua dimensão ferroviária, na segunda metade do século XIX. De fato, o conteúdo de história ambiental é diminuto perante a extensa atenção que o autor dedica à história política das grandes ferrovias dos EUA, seus dirigentes, financiadores, trabalhadores, amigos e inimigos políticos, e seus problemas financeiros, de engenharia e de logística. O mantra do livro, interpretado por mim, seria esse: Como alguns empreendedores construiram, com dinheiro alheio, ferrovias enormes e desnecessárias, e como eles acumularam fortunas pessoais enquanto as ferrovias faliram.

Esclarecer dois pontos ajuda a entender a posiçáo do autor e o conteúdo do livro. Primeiro, o título (Railroaded) é uma gíria-trocadilho intraduzível. O substantivo railroad (ferrovia) é transformado em verbo (railroaded), termo que indica que alguém muito forte "passou por cima" de alguém mais fraco. $\mathrm{O}$ termo não foi criado por White, mas ele o usa também como trocadilho no título de um livro sobre ferrovias. Ou seja, White sugere que as poderosas ferrovias transcontinentais passaram por cima de tudo e todos.

O segundo ponto é o significado de transcontinentals, palavra que aparece como substantivo no subtítulo. White estuda as ferrovias transcontinentais, cinco ou seis linhas cujo traço distintivo era interligar as costas atlântica e pacífica dos EUA. Esse adjetivo virou um substantivo no linguajar da época e na literatura histórica, e é assim que White o usa no título. É verdade que a ligação interoceânica passava primeiro por uma densa malha de ferrovias mais antigas, localizadas nos estados do litoral atlântico, do Meio-Oeste e do Sudeste dos EUA. As transcontinentais, construídas depois da Guerra Civil (1861-1865), tinham seus pontos de partida não na costa atlântica, mas em cidades situadas no eixo do rio Mississipi (Saint Paul, Duluth, Chicago, Des Moines, Omaha, Kansas City, Saint Louis, Nova Orleans etc.).

* Doutor em Land Resources pela University of Wisconsin, Estados Unidos, professor associado da Universidade de
Brasília, bolsista de produtividade científica do CNPq, nível 1D. Brasília, DF, Brasil. E-mail: jaldrummond@uol.com.br. 
Essas cidades já se conectavam aos estados do Leste e do litoral atlântico. De toda forma, quem partia de Nova York, por exemplo, fazia uma conexão em Chicago e dali podia cruzar todo o restante do território dos EUA, na direção Oeste.

Ou seja, as transcontinentais, quase paralelas entre si, corriam por cerca de $2.500 \mathrm{~km}$, dois terços da largura do território dos EUA, chegando a San Diego, San Francisco, Seattle e outras cidades portuárias do Pacífico. Reduziram o tempo da travessia terrestre entre os dois litorais de vários meses a apenas cinco ou seis dias. A essa enorme dimensão geográfica e ao seu efeito de "encolhimento espacial" correspondiam o tamanho e o poder das grandes corporaçóes que as operavam e que logo assumiram a estrutura de empresas monopolistas. Vale destacar que White presta mais atenção às empresas ferroviárias do que às linhas ferroviárias propriamente ditas. (Uma ótima coleção de imagens dessas ferrovias está disponível em http://memory.loc.gov/ammem/gmdhtml/rrhtml/ rrhome.html.)

O longo texto explora dezenas de questóes sobre essas ferrovias, mas selecionei para comentar nesta resenha as sete questóes mais extensamente focalizadas: as grandes ferrovias foram (i) economicamente desnecessárias, ou pelo menos precoces; (ii) caras em termos de finanças públicas e privadas (dos EUA e da Europa); (iii) mal geridas; (iv) cronicamente falimentares e desencadeadoras de pelo menos duas grandes crises econômicas de alcance nacional; (v) politicamente protegidas nos níveis nacional, estadual e local; (vi) indutoras de grandes desperdícios ambientais e de recursos naturais. Uma questão adicional, a sétima, é a do movimento sindical e grevista dos ferroviários empregados pelas transcontinentais.

Quanto ao primeiro ponto, White mostra que a distribuição das atividades produtivas, dos recursos naturais, da populaçáo e da infraestrutura de transportes dos EUA nos anos 1870 e imediatamente seguintes não justificava a construçáo de uma ferrovia transcontinental sequer, quanto mais meia dúzia delas. A sua enorme extensão encarecia construção, operação e manutenção. Elas atravessavam regióes esparsamente habitadas ou francamente desertas (algumas continuam assim até hoje) que não geravam cargas suficientes para cobrir custos fixos e operacionais. Adicionalmente, o leste dos EUA tinha uma economia dinâmica e próspera que não precisava naquele momento de múltiplas conexóes ferroviárias com o extremo oeste do país.

Por que elas foram construídas, então? White sugere que, à falta de uma justificativa propriamente econômica, elas foram motivadas por outros fatores. Um deles foi um sentimento difuso de otimismo tecnológico e modernizador característico de uma curta e dinâmica fase da história econômica dos EUA, conhecida como The Gilded Age ("a era folheada a ouro", 1878-1889). Entre os norte-americanos da época, a imagem de uma locomotiva cortando "terras selvagens" ("a máquina no jardim”, p. 225) era recorrente na arte e na imprensa. Despertava neles o orgulho de ser um povo moderno e criador de meios para explorar um grande território rico em recursos naturais. Contribuiu também para a construção dessas ferrovias uma vontade patriótica de "tomar posse" de todo o território nacional, inclusive a "fronteira" do Far West (Extremo Oeste), quase todo comprado da França (a compra da enorme Louisiana, ocorrida em 1803) ou tomado à força do México (depois da guerra de 1846-1847). Outro fator contribuinte foi o pleno domínio da plataforma tecnológica ferroviária pelos norte-americanos.

Entretanto, houve ainda uma motivaçáo propriamente financeira, o que nos leva ao segundo ponto. White assinala que otimismo, patriotismo e capacidade tecnológicas se casaram com o desejo de lucro (p. 9). Ele sustenta que as transcontinentais nasceram principalmente da percepção de alguns empresários e financistas (entre os quais havia aventureiros nada refinados) de que elas atrairiam investimentos públicos e privados de grande vulto. Ou seja, as ferrovias colocaram em jogo enormes quantias monetárias para investimentos num negócio promissor.

Em alguns casos, as ferrovias foram, de fato, consequências quase secundárias de vultosas e pouco transparentes movimentaçóes financeiras. White afirma que essas ferrovias "tiveram me- 
nos a ver com a obtenção de receitas geradas pelo transporte de pessoas e cargas e mais a ver com finanças e política" (p. 96). O ímpeto construtor de ferrovias era tão forte que, em 1889, 20\% dos $250.000 \mathrm{~km}$ de linhas ferroviárias existentes nos EUA tinham quatro anos ou menos de idade; a maior parte desses $50.000 \mathrm{~km}$ de linhas jovens correspondia às transcontinentais e a ramais conexos. Desses $250.000 \mathrm{~km}, 43 \%$ se localizavam nos estados do Oeste dos EUA, onde moravam apenas 24\% dos norte-americanos (p. 209).

Mesmo sujeitas a prejuízos, dívidas e falências, as ferrovias geraram grandes fortunas para os seus principais dirigentes, mas deram graves prejuízos para financiadores, acionistas, bancos, governos, clientes, empregados, fornecedores etc. Seus dirigentes "visionários", frequentemente enaltecidos como heróis do progresso e da riqueza, gostavam mesmo, segundo White, de "construir [ferrovias] com o dinheiro alheio" (p. 26). Eles tiveram amplo apoio do erário público dos governos nacional e estaduais (nas formas de subsídios, doações de terras, liberação de tarifas, perdão de dívidas, garantias, isenção de impostos etc.), além de favores menores de governos locais.

$\mathrm{O}$ terceiro ponto $-\mathrm{o}$ da incompetência gerencial - é revelado cruamente pelo fato de White usar extensamente as desinibidas correspondências pessoais dos principais dirigentes das ferrovias, chamados na literatura de railroad barons ("barôes das ferrovias"), expressão nada elogiosa. É impossível discordar de White sobre a condição invariavelmente incompetente, frequentemente oportunista e aventureira, e não raramente criminosa, de cerca de duas dúzias dos barôes que geriram as transcontinentais (os seus sobrenomes são famosos até hoje nos EUA Harriman, Cooke, Gould, Adams, Huntington, Stanford e outros).

Violavam contratos e leis; rompiam acordos que faziam entre si; cometiam erros em série; eram imprevidentes; tratavam truculentamente clientes e comunidades locais. Oscilavam entre se engajar numa concorrência mutuamente destrutiva e fazer entre si acordos cartelizantes, combinando tarifas e racionando serviços. Arquitetavam opera- çóes financeiras ilegais ou ao menos sombrias (pagando dívidas vencidas com o dinheiro de novos investidores, por exemplo), quase sempre para prejudicar concorrentes, e não para melhorar a situação financeira e operacional das suas respectivas ferrovias; combatiam duramente os sindicatos de ferroviários, demitiam em massa grevistas, faziam "listas negras" de trabalhadores sindicalizados e contratavam trabalhadores ilegais (principalmente chineses). Em vários casos, depois de as ferrovias terem suas falências decretadas, os seus gerentes "ressuscitavam", com suas fortunas incólumes, e se reinseriam nos negócios ferroviários. Isso leva White a comentar que o "sistema [das transcontinentais] não enterrava os seus mortos" (p. 223).

O quarto ponto é ilustrado pelas duas grandes crises financeiras e econômicas, de âmbito nacional, uma em 1873 e anos seguintes e outra que começou em 1893. Quase todos os estudiosos dessas crises as atribuem aos gastos excessivos e à falta de eficiência das transcontinentais. White não diverge desse consenso. Pelo contrário, ele segue meticulosamente o rastro dos dinheiros públicos e privados investidos nas ferrovias e que nela se dissipavam. White considera que a crise nacional de 1893 "foi a mais profunda depressão ocorrida na história dos EUA até a Grande Depressão dos anos 1930" (p. 393). Mais de um quarto do capital e dos ativos das grandes companhias ferroviárias caiu nas mãos de administradores de massas falidas nomeados pela justiça. Mas, pessoalmente, os barôes e seus associados mais próximos (insiders) sempre saíam das crises com o seu próprio dinheiro em caixa, deixando os prejuízos para comunidades e governos locais, governos estaduais, bancos, investidores individuais ou corporativos, inclusive alguns gigantes financeiros da costa leste. Essas graves crises abalaram seriamente e deixaram cicatrizes profundas na emergente economia norte-americana, tanto a oeste como a leste. White não deixa dúvidas de que as crises das seis ferrovias gigantes foram de fato capazes de desencadear essas duas crises, embora aponte algumas causas concorrentes.

O quinto ponto é que os baróes cantavam publicamente a melodia do individualismo, da 
livre-iniciativa e do liberalismo, mas White mostra que as suas ferrovias foram invariavelmente corporaçóes financiadas pelo dinheiro público e protegidas de diversas formas por políticos de quase todas as cores e filiações partidárias. White as considera as primeiras grandes corporaçóes dos EUA. O capítulo 3, intitulado Friends ("Amigos"), mostra como os barōes se engalfinhavam para, com poucos rodeios e menos escrúpulos, comprar "amigos" (inclusive legisladores federais e estaduais, além de governadores de estado) para obter favores dos governos, órgãos reguladores das ferrovias, assembleias legislativas estaduais, congresso nacional e até jornais influentes.

Juntamente com as concessóes de serviço, as empresas ferroviárias dos EUA geralmente ganhavam faixas de terras públicas ao longo dos seus traçados, para explorar diretamente, vender ou arrendar, a fim de obter receitas extras. No caso das longuíssimas transcontinentais, essas concessões formavam áreas enormes. As empresas viravam estados dentro dos estados propriamente ditos. Junto com esse status vinha, evidentemente, a capacidade de influir na política e no desenvolvimento locais. É verdade que as transcontinentais sofreram com a oposição sistemática de grupos e coalizóes antimonopolistas e que até perderam alguns privilégios importantes por causa disso, mas elas acabaram falindo menos por causa dessa oposição e mais por causa de suas dimensóes gigantescas e de seu gerenciamento falho ou criminoso.

Isso leva ao sexto ponto entre os mais focalizados por White. As ferrovias, por deterem essas grandes parcelas de terras e riquezas conexas, influenciaram fortemente os padróes de ocupação dos estados que cortavam. Elas condicionavam a distribuição da população e estimulavam as práticas invariavelmente predatórias de exploração de recursos naturais adotadas por vários atores. Isso é tratado principalmente no capítulo 11, no qual se concentra a maior parte do conteúdo de história ambiental do livro. A título de ilustração, três transcontinentais detinham cerca de $62.000 \mathrm{~km}^{2}$ de terras (1,5 vez o tamanho do atual estado do Rio de Janeiro), e isso apenas em dois estados onde estavam os terminais de suas linhas, Califórnia e Oregon (p. 459).

Essa influência das transcontinentais se manifestou de muitas maneiras. Elas mantiveram (ou se associaram com) companhias de imigração, que atuaram diretamente nos países europeus para atrair pessoas que ocupassem as terras em suas áreas de influência. Onde havia bons solos, por exemplo, as ferrovias estimularam a agricultura familiar, confiável produtora de cargas. Faziam isso mesmo em regióes sabidamente semiáridas e áridas situadas a oeste do meridiano 98 , nas quais a precipitação caía abaixo dos $600 \mathrm{~mm}$ anuais considerados minimamente necessários para a agricultura sem irrigação. Nos bons pastos nativos das prairies (pradarias), as ferrovias favoreceram a criaçáo de gado pelos pecuaristas, seus maiores aliados nos territórios atravessados. Onde havia depósitos minerais e florestas impróprios para a agricultura familiar, as ferrovias os arrendaram a empresas dos dois ramos e escoaram as cargas volumosas e pesadas (dois exemplos notáveis foram o carvão e a madeira em tora). As ferrovias deram apoio logístico à virtual extinção do bisão, cujos territórios elas cortaram e cujos couros representaram por algum tempo uma de suas principais cargas. Algumas ferrovias apoiaram a criação de parques nacionais, de olho nas passagens e nos serviços de apoio a serem oferecidos aos seus visitantes.

White registra mais brevemente outros fatos e processos ligados às terras controladas pelas ferrovias. Algumas cruzaram, legal ou ilegalmente, reservas indígenas, gerando conflitos e desapropriaçôes que, em última instância, levavam à redução das reservas ou à expulsão de seus habitantes. As ferrovias por vezes usaram as terras concedidas como garantia para a tomada de empréstimos junto a bancos e a investidores, ou ainda como lastro para o lançamento de títulos. Esses usos "financeiros" das terras descambaram várias vezes para atos de especulação e de fraude (por exemplo, colocar como garantia lotes vendidos, inexistentes, alheios ou arrendados).

O sétimo ponto tratado extensamente por White, que consta dos capítulos 6 e 7, princi- 
palmente, é o dos trabalhadores ferroviários. Ele usa uma narrativa que lembra o do recentemente falecido Eric Hobsbawm (1917-2012). Fala de suas origens sociais e geográficas, de seu caráter frequentemente volante ou temporário, de seus sindicatos, associaçóes e greves, dos afazeres e dos acidentes de trabalho. Mostra que muitos ferroviários eram agressivamente xenófobos e racistas, hostis a trabalhadores chineses e negros. Mostra ainda que os empregos nas ferrovias eram geralmente desejados e bem pagos, o que fazia com que os muitos dos seus empregados vacilassem em aderir mesmo ao moderado "trade-unionismo" que dominava as suas associaçóes.

Cada capítulo se fecha com uma vinheta de fundo biográfico, narrando episódios das vidas individuais de dirigentes ferroviários, trabalhadores comuns, diretores de segundo escaláo etc. Essa interessante solução de narrativa permite que White dê "rostos humanos" a algumas de suas passagens mais áridas, aumentando a legibilidade do texto como um todo.

$\mathrm{Na}$ p. 515, White resume o que descobriu sobre as transcontinentais: "Celebradas como conquistadoras do tempo, dos espaços, e mesmo da própria natureza, as ferrovias do Oeste foram sempre mais uma promessa do que uma conquista. Eles foram menos um ativo que uma geração repassou para a próxima e mais uma dívida que o passado impôs ao presente e ao futuro". Dessa forma, elas foram o oposto do que hoje chamamos de "sustentáveis", pois que deixaram toda sorte de passivos para as geraçóes futuras.

As 107 páginas de notas impressionam o leitor leigo e mesmo o profissional. Elas incluem as instituiçóes de arquivamento dos materiais primários e as referências bibliográficas dos materiais impressos consultados. Os variados e volumosos documentos primários usados por White forneceram a maior parte das informaçóes do texto. Eles incluem arquivos e relatórios das companhias ferroviárias; arquivos pessoais, correspondências profissionais e particulares, e textos memorialísticos dos principais gerentes das grandes ferrovias; ma- teriais de museus ferroviários e arquivos públicos de vários estados e cidades; documentos de sindicatos de ferroviários; registros, processos e sentenças judiciais; documentos parlamentares federais e estaduais; materiais das agências reguladoras das ferrovias; correspondência de investidores norte-americanos e europeus; documentos bancários e de escritórios de investimentos; recortes de jornais; e panfletos e materiais propagandísticos das ferrovias. Os relatórios e as investigaçóes dos administradores das massas falidas das transcontinentais são outras fontes primárias especialmente úteis para revelar as práticas gerenciais desastrosas/criminosas dos barôes.

White usa economicamente a extensa bibliografia analítica publicada. As grandes ferrovias eram populares em sua época e até hoje atraem a atenção de numerosos estudiosos. Isso gerou um grande número de análises e relatos sobre elas trabalhos acadêmicos, memorialísticos, documentários e depoimentos de época. Como bom revisionista, no entanto, White adota os seus próprios ângulos analíticos e chega às suas próprias conclusôes, sem reproduzir ou depender fortemente de qualquer um dos analistas do passado ou atuais.

No todo, o relato extenso, meticuloso, bem documentado e exasperante de White demole uma persistente mitologia que até hoje vê nas ferrovias transcontinentais atores imbuídos de heroísmo, pioneirismo, ousadia, eficiência e capacidade "civilizatória". Trata-se de um desses livros que, aparentemente, veio para reinar sobre uma área de conhecimento por várias décadas. Não é amigável para iniciantes nos assuntos tratados, mas as pessoas de fato interessadas nesses assuntos não podem ignorá-lo. $\mathrm{Na}$ área universitária, é um livro apropriado para cursos avançados em história da América, história das fronteiras e história econômica. Para o público leigo, o texto é detalhado e técnico demais para ser atraente. Reitero que não se trata de um livro de história ambiental estrito senso, não para criticar o livro ou o autor, mas apenas para alertar os que se interessam pelas produçóes de história ambiental de White. 